\title{
Social Security Incidence under Uncertainty Assessing Italian Reforms
}

\author{
Devis Geron
}

CESIFO WORKING PAPER No. 2812

CATEGORY 1: PUBlic FinANCE

OCTOBER 2009

Presented At CESifo Venice Summer Institute, July 2009

\footnotetext{
An electronic version of the paper may be downloaded

- from the SSRN website:

- from the RePEc website:

- from the CESifo website:

www.SSRN.com

Www.RePEc.org

www.CESifo-group.org/wp
} 


\title{
Social Security Incidence under Uncertainty Assessing Italian Reforms
}

\begin{abstract}
This paper analyzes the welfare effects of the Italian social security system in an economy with uncertainty on wages, financial market returns and life expectancy. The introduction of a pension system reproducing the Italian statutory scheme turns out to decrease ex-ante individual welfare, unless restrictions are assumed on retirement behavior. Overall, risk insurance effects of social security play a minor role in determining welfare variations. The new Italian NDC pension system is shown to yield a slight ex-ante welfare improvement from a purely risk-insurance perspective. This relative gain stems from risk diversification across working-life wages in computing benefits.
\end{abstract}

JEL Code: E62, H55, H21, H31.

Keywords: social security reforms, uncertainty, risk insurance.

\author{
Devis Geron \\ Department of Economics \\ University of Padova \\ Via del Santo 33 \\ 35123 Padova \\ Italy \\ devis.geron@unipd.it
}

September 2009

I am very grateful to Luciano Greco, Guglielmo Weber, Laurence J. Kotlikoff, Alessandro Bucciol, Nunzio Cappuccio and Efrem Castelnuovo for their help and advice. I wish to thank the participants of the Public Economics PhD Workshop 2009 at the Institute for Fiscal Studies in London, the participants of the 7th International Workshop on Pension, Insurance and Saving at the University of Paris-Dauphine, the participants of the Public Economic Theory 2009 Conference in Galway, and the participants of the Workshop 'Rethinking the Privatization of Social Security' at the 10th CESifo Venice Summer Institute for insightful comments. I also wish to gratefully acknowledge CESifo sponsorship for the Workshop 'Rethinking the Privatization of Social Security', held in Venice on the $10^{\text {th }}$ and 11 th July 2009. 


\section{Introduction}

Economic and demographic trends over the last decades have induced the need to reform Pay-As-You-Go (PAYG) pension programs and restore their financial sustainability. These issues raise some fundamental questions that have been widely investigated by the economic literature: are there economic reasons that could still justify the existence of PAYG pension systems? What are the effects we should expect to obtain from systemic or marginal reforms? What is the "desirable" size of social security?

When considering the effects of fiscal reforms and the distribution of gains and losses among generations, one useful tool of analysis is the generational accounting methodology, first introduced by Auerbach, Gokhale and Kotlikoff (1991, pp. 55-110). It aims at estimating variations in the generational accounts, i.e. lifetime net taxes, of every living and future generation.

An important remark to the generational accounting literature is that it fails to consider uncertainty in estimating welfare effects. Neglecting uncertainty leaves out a crucial part of actual overall welfare variations. In particular, many recent studies (Campbell and Nosbusch 2007, pp. 2251-2268; Gottardi and Kubler 2009; Krueger and Kubler 2006, pp. 737-755) have emphasized the role played by social security in increasing individuals' welfare. Social security systems, especially of PAYG type, have indeed been shown in the literature to be capable of enhancing risk insurance in the presence of uncertainty (on factor returns, demographic trends, future fiscal policy decisions, and so on), dating back at least to contributions by Enders and Lapan (1982, pp. 647-658) and Merton (1983, pp. $325-358)$.

In general, risk insurance causes risk-averse individuals to enjoy some ex-ante welfare improvement, due to a reduction in the variability of lifetime income (and thus consumption) flows.

A first form of insurance is provided against the well-known "longevity risk" (Barr 
and Diamond 2006, pp. 15-39). Moreover, every individual faces mortality risk during lifetime, potentially causing them to die without having consumed all of their savings, thus accidentally (in the absence of a bequest motive) leaving some resources not utilized, that is clearly sub-optimal from an individual's perspective. In the absence of annuity markets a social security system is likely to be welfare-increasing (Imrohoroglu, Imrohoroglu and Joines 1995, pp. 83-114), since it provides insurance against those risks by paying pension benefits to retirees in the form of annuities, in exchange for contributions they paid in while working. ${ }^{1}$

PAYG social security systems may also offer risk insurance tools in the absence of other markets as well. The literature has concentrated in particular on the inefficient allocation of risks among different generations. A Pareto efficient allocation of risks could be reached if all generations could ex-ante trade with each other in contingent-claims markets à la Arrow-Debreu. This efficient allocation however cannot be reached in economies with different generations overlapping through time, because individuals cannot trade in risksharing with individuals of other generations who are not yet born (Ball and Mankiw 2001, pp. 523-547). There is therefore room for government to introduce a (contingent) social security system letting different generations share demographic and macroeconomic risks, typically by providing pensioners with claims to labor income (Krueger and Kubler 2006, pp. 737-755), or also workers with claims to physical capital. Social security is in fact an additional asset yielding a return whose degree of correlation with returns on other assets - notably on individual savings - crucially determines insurance of individuals through diversification of risks.

All of the previous points suggest that analyzing the incidence of social security requires uncertainty to be taken into account.

\footnotetext{
${ }^{1}$ Annuity markets are actually narrow in real economies, seemingly contradicting predictions of the traditional life cycle model. The literature has traditionally identified possible explanations for this "annuity puzzle", notably low yields on annuities (also due to costs related to adverse selection) and the presence of a bequest motive (Friedman and Warshawsky 1990, pp. 135-54).
} 
Most of the analysis on the Italian pension system so far has been concerned with changes in both individual transfers and social security financial viability resulting from pension reforms. In particular, some studies have estimated the impacts of reforms from a generational accounting perspective (Cardarelli and Sartor 2000, pp. 501-557) and the effects on social security financial sustainability (Sartor 2001, pp. 83-111). Another strand of the literature on Italian pension reforms has been concerned with impacts related to intra-generational redistribution (Fonseca and Sopraseuth, 2005). No studies on the Italian pension system have yet analyzed the potential policy-induced welfare changes resulting from aggregate risk insurance, when uncertainty is taken into account in its different demographic and macroeconomic - dimensions.

This paper is aimed at investigating the Italian social security system in a setting where individuals face both mortality risk and uncertainty on factor returns, i.e. aggregate wages and financial market yields. The focus is on the welfare enhancement potentially resulting from risk insurance provided by social security under market incompleteness, notably in the absence of contingent-claims markets (à la Arrow-Debreu) and particularly of annuity markets.

By applying the salient features of the Italian pension system to a model representing the Italian economy, the paper firstly analyzes whether social security can actually improve individual welfare in the presence of macroeconomic and demographic risks under market incompleteness. The introduction of a social security system reproducing the statutory Italian pension scheme and being allowed to run within-period deficits turns out to decrease ex-ante welfare of individuals in the model, unless individuals in the absence of social security are assumed to retire at a relatively early age due to some exogenous reason (e.g. some "shock" worsening their health conditions). If the social security budget is constrained to balance in every period, the optimal size of both the old and the new Italian pension regime turns out to be positive but close to zero, therefore considerably 
lower than the actual size of the Italian pension system.

Secondly, the paper performs a comparison between the "old" Italian pension system and the "new" system introduced in the mid 1990s. From a purely risk-insurance perspective the new regime proves to slightly improve ex-ante welfare, plausibly due to its capability of performing better risk diversification across all working-life wages in computing pension benefits. This result is robust to different specifications of the main parameters in the model.

Overall, risk-insurance effects of social security do not seem to significantly drive welfare gains and losses, and appear instead to be largely outweighed in magnitude by other components of the overall welfare variation.

The paper is organized as follows. Section 2 presents the model. Section 3 illustrates the policy experiments that are considered, and presents the main findings. Section 4 concludes.

\section{The Model}

The model considers a discrete time setting (every period in the model corresponds to one year in real life) representing a partial equilibrium economy where both wages and market returns are completely determined by foreign markets. ${ }^{2}$

The economy is thus affected by two main sources of macroeconomic uncertainty, that are only partially correlated: wages and market returns. The pre-tax income of every individual in every period $t$ is determined by a stochastic real average market return $r_{t}$ on

\footnotetext{
${ }^{2}$ Italy can be approximately regarded as a small open economy worldwide and, by further approximation, in the European Union. The paper assumes that real financial returns and wages are determined by European capital and labor markets. This assumption is quite realistic as regards interest rates. As for wages, although the European labor market is not integrated, the high-level integration in the European markets of goods can be thought of as influencing the determination of Italian real wages through the prices of tradable goods, in the wake of the Stolper-Samuelson theorem.
} 
their savings (government bonds, corporate bonds, stocks) and by a stochastic real wage $w_{t}$ earned during working life. After retirement, every individual receives a pension benefit that is linked to their wages during their working lives, according to a given benefit rule.

The model also takes into account yearly average wage growth, both at the aggregate level (growth rate of labor productivity $g$ ) and at the cohort-specific level (seniority wage growth $s w)$. Both growth rates are assumed to be constant and to enter the model as exogenous deterministic trends that are applied to the underlying stochastic dynamics of wages $w_{t}$.

The economy is populated by different generations overlapping through time. For each generation, a representative individual is considered. All representative individuals are identical. Total population mass grows at a deterministic constant rate $m$ from every period to the next.

Representative individuals live in the economy from age 1 to at most $T$ years. Individuals aged $t$ (with $t=1, \ldots, T$ ) survive to age $t+1$ with a given (age-dependent) conditional survival probability, and they are assumed to know all survival probabilities. ${ }^{3}$ Besides macroeconomic risks on wages and market returns, a further source of uncertainty in the model is thus represented by mortality risk.

Each representative individual ex-ante maximizes expected discounted lifetime utility with respect to within-period consumption and within-period leisure. Maximization occurs at (just before) the beginning of life, i.e. at time $t=0$, prior to entering the economy and thus before knowing the realized values of any stochastic variable affecting utility in the future periods $(t=1, \ldots, T)$ :

$$
E_{0}\left[\sum_{t=1}^{T} \beta^{t-1}\left[\prod_{k=1}^{t} \psi_{k}\right] U_{t}\left(c_{t}, l_{t}\right)\right]
$$

where $\beta$ in the above formula is the subjective time discount factor; $\psi_{t}$ is the conditional survival probability from age $t-1$ to age $t$, with $\psi_{1}=1$ and $\psi_{T+1}=0 ; c_{t}$ and $l_{t}$ are

\footnotetext{
${ }^{3}$ Hereafter, where considering a single representative individual in the economy, both time periods and the individual's age are denoted by $t$ (with $t=1, \ldots, T$ ).
} 
respectively consumption and leisure entering the utility function of agents at age $t$. The within-period utility function takes the CES form:

$$
U_{t}\left(c_{t}, l_{t}\right)=\frac{1}{1-\rho}\left(c_{t}^{1-\sigma}+\gamma_{t} l_{t}^{1-\sigma}\right)^{\frac{1-\rho}{1-\sigma}}
$$

where $\frac{1}{\rho}$ is the intertemporal elasticity of substitution between consumption of different years, $\frac{1}{\sigma}$ is the intratemporal elasticity of substitution between consumption and leisure, and $\gamma_{t}$ represents the time-varying leisure preference parameter. The leisure preference parameter is plausibly assumed to be increasing over time and inversely proportional to survival probabilities $\left(\psi_{t}\right)$, according to the following formula:

$$
\gamma_{t}=\alpha+\frac{\kappa}{-\omega+\tau\left(\psi_{t}^{\theta}\right)}
$$

with

$$
\alpha=\frac{\kappa}{\psi_{1}}-\frac{\kappa}{-\omega+\tau\left(\psi_{1}^{\theta}\right)}
$$

In every period $t$ individuals are provided with a given time endowment $\bar{T}$, and choose consumption $c_{t}$ and labor supply $\bar{T}-l_{t}$.

Every individual works and receives a wage $w_{t}$ for each unit of time spent working, i.e. a total wage $w_{t}\left(\bar{T}-l_{t}\right)$, at every age $t$ (if alive), until they choose to retire at age $t_{r e t}$. While working, individuals pay in social security contributions at a rate $h$ out of their labor income. After retirement $l_{t}$ is equal to $\bar{T}$ and retirees receive a pension benefit $p_{t}$ at every age $t$ (if alive) until death at $T$.

The within-period budget constraint of a given individual at every age $t$, assuming the world starts at time $t=1$, would therefore read as follows:

$$
\begin{aligned}
& A_{t+1}=A_{t}\left(1+r_{t}\right)+(1-h) w_{t}(1+g)^{t-1}(1+s w)^{t-1}\left(\bar{T}-l_{t}\right)-c_{t} \quad \text { for } t=1, \ldots, t_{r e t}-1 \\
& A_{t+1}=A_{t}\left(1+r_{t}\right)+p_{t}-c_{t} \quad \text { for } t=t_{r e t}, \ldots, T
\end{aligned}
$$

where $A_{t}$ represents the beginning-of-period asset holdings of the individual aged $t$.

Agents are assumed to be borrowing constrained:

$$
A_{t} \geq 0 \quad \text { for } t=1, \ldots, T
$$


Furthermore the model assumes there is no bequest motive, thus individuals do not leave any bequest in case they live until age $T: A_{T+1}=0$.

In case the individual dies before reaching age $T$, his accumulated assets, i.e. accidental bequests, are assumed to be destroyed and provide no utility to other individuals who are still alive. ${ }^{4}$

Markets in the model are incomplete. In addition to individuals being borrowing constrained, two other main sources of market incompleteness are considered. Firstly, and quite realistically, agents in the economy cannot insure against uncertainty by trading contingent claims à la Arrow-Debreu. Secondly, annuity markets are assumed to be missing. This latter assumption reflects the very small size of the current Italian annuity market (Guazzarotti and Tommasino 2008).

It can be noticed that the absence (or the relatively small size) of annuity markets in general, also implies in particular the absence of privately-provided annuities yielding wage-based returns, that are instead typically publicly provided through social security especially under (Pay-As-You-Go) Defined Benefit pension systems.

Government is assumed to enter the model only through running an unfunded social security system. The contribution rate $h$ in the baseline model is exogenously determined so as to match the statutory contribution rate in the Italian social security system. Where optimality analysis is performed, the contribution rate is endogenously determined so as to guarantee the within-period balance of social security budget.

\footnotetext{
${ }^{4}$ This assumption is made for the sake of simplification when performing numerical computations. It does not affect - per se - the main results of the paper regarding risk-insurance effects of social security, since it only deals with the distribution of accidental bequests across individuals. Alternative assumptions regarding accidental bequests may involve redistributing unintended bequests to all or some of the surviving generations according to some criteria, e.g. in a lump-sum fashion or proportionally to wealth conditions of the survivors.
} 


\subsection{Calibration and Optimization Problem}

In order to solve the optimization problem, the parameters of the model are assigned specific values resulting from an appropriate calibration aiming to replicate stylized facts of the Italian economy, notably lifetime labor and consumption paths of individuals. In particular, the calibrated lifetime consumption path slightly increases in line with wage growth during working life, and drops at retirement. The simulated consumption drop at retirement under the old pension regime in the model lies between $7 \%$ and $8 \%$, and is comparable to the drop empirically measured for Italy (Miniaci, Monfardini and Weber 2003; Battistin et al. 2008) under the old regime (prior to the 1992 Amato reform and as modified by the Amato reform).

The benchmark economy utilized in the calibration is the Italian economy under the old pension system, i.e. the pension regime before the introduction of the 1992 reform (the so-called Amato reform). Because the old pension regime has been uniquely or mostly applied in Italy so far - even after reforms in the 1990s, due to a long transition period set by law - it represents the most suitable regime to be considered when calibrating the model to reproduce reality. While applying the main statutory features of the old regime, the calibration utilizes a replacement rate lying within a range that reasonably includes the actual replacement rate enjoyed at retirement by individuals in Italy under the old system: according to OECD (2007) estimates, the actual average (net) replacement rate was plausibly above $90 \% .^{5}$

The model specification resulting from the calibration constitutes the "baseline" model, i.e. the reference setting for all simulations. The baseline model is characterized as follows.

Each representative individual - representing both males and females - is assumed to

\footnotetext{
${ }^{5}$ The Italian pension system in the past decades was particularly advantageous to pensioners, so that the actual replacement rate under the old scenario was higher than the one statutorily set. This situation was due to several favorable conditions generally enjoyed by retirees, such as opportunities of early retirement (e.g. the so-called "baby pensions" to public sector employees) and relatively high pension benefits.
} 
enter the economy when 21 years old, corresponding to the first lifetime period $(t=1)$ in the model. This reflects the real average entry age in the labor market in Italy.

Assets held by individuals at the beginning of their (economic) life are assumed to be equal to zero: $A_{1}=0$.

Agents live at most 80 years $(T=80)$, i.e. until they are actually 100 years old, surviving from every period to the next with a certain (conditional) survival probability.

The sequence of conditional survival probabilities $\left\{\psi_{t}\right\}_{t=1}^{T}$ is computed as the weighted average of survival probabilities per cohort of Italian males and females in 2004, reported by the yearly demographic balance of Istat (Italian National Institute of Statistics). ${ }^{6}$

In the baseline calibration, population mass in every period is equal to one, i.e. yearly population growth rate is equal to zero: $m=0$. This is in line with recent demographic trends and with demographic projections for Italy. According to the Istat demographic balance, the Italian population in the 1990-2004 period has experienced an average yearly population growth rate equal to $0.15 \%$. Istat demographic projections for the 2007-2051 period, under the so-called "central" scenario, forecast an average yearly population growth rate close to zero, namely $0.1 \%$.

Econometric analysis on Italian wages and market returns (see Appendix for details) suggests that the processes underlying wages $\left(w_{t}\right)$ and market returns $\left(r_{t}\right)$ can be represented as follows:

$$
w_{t}=38.7227+0.6451 * w_{t-1}+e w_{t}
$$

where $e w_{t}$ is the error term, normally, identically and independently distributed with mean zero and variance $\sigma_{w}^{2}=2.9932$.

$$
r_{t}=0.0656+e r_{t}
$$

where $e r_{t}$ is the error term, normally, identically and independently distributed with

${ }^{6} 2004$ is one of the last years as of which data are available, and is in line with most time spans for data utilized in the calibration. 
mean zero and variance $\sigma_{r}^{2}=0.01798$.

Wages in the model therefore follow an autoregressive process. Market returns are instead estimated to consist of an i.i.d. random variable $\left(e r_{t}\right)$, around a constant mean value. The covariance between the error terms $e w_{t}$ and $e r_{t}$, denoted as $\sigma_{w r}$, represents the degree of correlation between the stochastic component of wages and market returns. It is estimated as

$$
\sigma_{w r}=0.0557
$$

suggesting a slight positive correlation between wages and market returns.

The deterministic yearly growth rate of aggregate real wages is assumed to be zero: $g=0$. This is in line with the average yearly growth rate of real compensations per employee in period 1990-2004, that was roughly zero: according to OECD (2008) data for Italy, average growth rate of real compensations in 1990-2004 was approximately equal to $-0.04 \%$.

The only source of deterministic wage variation through time is a cohort-specific component tracking changes in wages due to career dynamics, namely to seniority-driven (contractual) increases in wages. This is consistent with an aggregate growth of real wages equal to zero, since seniority growth of real wages regards every single cohort, under the assumption - made in the model - that contractual wage dynamics is constant throughout generations. By approximation based on OECD (2008) and Bank of Italy (Rosolia and Torrini 2007) data, the average yearly "seniority" growth rate in real wages is set at $s w=2 \%$.

Since $m=0$ and $g=0$, the overall yearly growth of the economy in the baseline scenario is equal to zero. Moreover, seniority wage growth (sw) is assumed to remain constant throughout generations. Consequently, no macroeconomic or demographic effects influence welfare levels of different generations under different pension systems through time. 
This assumption of no economic growth through time, along with the partial equilibrium assumption, provide an advantage when performing welfare analysis: instead of considering several overlapping generations through time, the whole analysis throughout the paper will focus on a "steady state" single representative individual under different social security systems, without loss of generality in the results.

Preference parameters are calibrated as follows:

$$
\begin{aligned}
& \beta=0.99 \\
& \rho=0.9 \\
& \sigma=0.284
\end{aligned}
$$

The parameters entering the formula of the leisure preference parameter $\gamma_{t}$ are calibrated as follows:

$$
\begin{aligned}
\kappa & =25 \\
\omega & =0.025 \\
\tau & =0.15 \\
\theta & =2
\end{aligned}
$$

The values for the above parameters are such that the individuals' (simulated) optimal economic decisions in the model well reproduce those observed in reality. ${ }^{7}$

In particular, the value assigned to $\rho$ lies in the range between 0.5 and 1.5 that can be considered as a "reasonable" range for the reciprocal of the intertemporal elasticity of substitution (Battistin et al. 2008). The subjective time discount factor $\beta$ is also in line with values commonly utilized in the literature.

Social security in the model reproduces the main actual features of the different pension systems in Italy. In case the contribution rate is exogenously fixed, it is equalized to the statutory average contribution rate on wages of employees under different Italian pension regimes (as described below).

\footnotetext{
${ }^{7}$ The model would fit reality quite well also in case preference parameters were assigned different values around the calibrated values, lying in ranges utilized in the literature.
} 
Considering the calibrated model, the solution to the corresponding optimization problem for a representative individual entering the economy at age $t=1$ is a sequence of optimally chosen values for consumption $\left(\left\{c_{t}^{*}\right\}_{t=1}^{T}\right)$ and leisure $\left(\left\{l_{t}^{*}\right\}_{t=1}^{T}\right)$ maximizing the individual's expected discounted lifetime utility (measured at time $t=0$ ). ${ }^{8}$ The solution is found by numerically simulating the calibrated model: each analysis in the paper is carried out through running 10000 simulations.

\section{Simulations and Findings}

Simulations are run by applying to the model various social security schemes reproducing different past and current pension regimes in Italy.

\subsection{The Italian Pension System}

The major Italian pension reforms considered in the model are the so-called Amato reform (1992) and Dini reform (1995).

Before the introduction of the Amato reform (i.e. under the "pre-Amato", or "old" regime) the Italian pension system was an unfunded defined benefit system (PAYG-DB), in which pension benefits were based on wages earned in the last five years of working life (only on last year's wage for public sector employees). Individuals were allowed to retire after 35 years of work and contribution to social security (20 years for public sector employees), or alternatively when they were 60 years old (55 for females) with at least 15 years of contribution. Pension benefits were computed by applying to the average wage over the last five working years a replacement rate equal to $2 \%$ for every year of work and contribution. The maximum possible replacement rate was equal to $80 \%$ (corresponding

\footnotetext{
${ }^{8}$ When practically solving the optimization problem, in every period $t$ consumption $\left(c_{t}\right)$ is substituted with assets at the beginning of next period $\left(A_{t+1}\right)$ as a choice variable, according to the relation between $c_{t}$ and $A_{t+1}$ derived from the budget constraint.
} 
to 40 years of work) for individuals working 40 years or more. The pre-Amato contribution rate was approximately equal to $24 \%$.

The 1992 Amato reform basically tightened the rules of the pension system ("postAmato" or "pre-Dini" regime) through parametric variations, while keeping unchanged its systemic, i.e structural, aspects. The Amato reform provided that pension benefits would be computed by applying the replacement rate $(2 \%$ for every year of work and contribution) to the average of all wages earned throughout the entire working life. The contribution rate was set at $27 \%$.

The 1995 Dini reform instead changed the Italian pension system ("post-Dini", or "new" regime) to a greater extent, by turning it from DB into NDC (notional defined contribution). In order to compute pension benefits, Social Security contributions are "notionally", i.e. fictitiously, capitalized at a rate that is linked to the growth rate of the economy during working life, and the amount accumulated in this way at retirement is turned into annuities through multiplying it by statutory annuity rates (so called "transformation coefficients"). Dini reform allowed individuals to choose their retirement age from any age between 57 and 65 years (with a minimum required number of years of contribution). Annuity rates vary according to the age at which an individual chooses to retire (the higher the retirement age, the greater the annuity rate, and the greater the pension benefit), and are periodically revised in order to account for changes in the (average) life expectancy of population. Individuals under the post-Dini system may also choose to retire later, i.e. after 65: in this case the annuity rate (transformation coefficient) utilized in the benefit rule remains constant thereafter, and equal to the annuity rate applied in case of retirement at 65 . The contribution rate, currently in force, was set at $33 \%$.

A transition period was set by law: whoever at the end of 1995 had contributed for more than 18 years, is not affected by Dini reform; for whomever entered the labor market after 1995, Dini reform fully applies; for those having contributed to social security for 
less than 18 years at the end of 1995, a mixed regime applies, with pension determined pro-rata (proportionally to time spent contributing before and after 1995). ${ }^{9}$

The above described features of the Italian pension system are reproduced (slightly simplified) in the model. Following the approach of Cardarelli and Sartor (2000, pp. 501557), comparisons across regimes in the paper are performed between the system before the Amato reform (old regime) and after the Dini reform (new regime).

\subsection{Main Findings and Discussion}

As outlined in the previous Section, the baseline model is calibrated so as to reproduce the main features of the benchmark Italian economy as closely as possible. From the corresponding simulations it turns out that individuals in the model under the actual old pension system choose to retire as soon as they are statutorily allowed to (i.e. after 35 years of work and contribution, corresponding to retirement at 56 real-life years) since they enjoy a very high effective replacement rate, as it was actually the case in Italy under the old regime.

When optimization is instead performed under the statutory features of the pre-Amato system, individuals turn out to choose to retire at a later age than the minimum allowed by the system: in the simulated model, it is optimal for individuals under the old system to work for 40 years, corresponding to retirement at $t_{r e t}=41$ in the model, i.e. 61 (real-life) years. After working for 40 years, the ceiling to the replacement rate (no longer increasing after 40 years of contribution) seems to provide an incentive to retire.

Under the statutory post-Dini system, ex-ante optimization requires individuals to choose to retire after working for 44 years, corresponding to retirement at $t_{r e t}=45$ in

\footnotetext{
${ }^{9}$ The last major reform introduced in Italy in 2004, the so-called Maroni reform, basically preserved the post-Dini regime, but set a gradual increase in the minimum retirement age from 60 years in 2008 to 62 years in 2014 onwards. Moreover, the Maroni reform provided some incentives for workers to invest their accrued severance pay into pension funds, on an individual voluntary basis.
} 
the model, i.e. 65 (real-life) years. The statutory "ceiling" on benefit computation (the annuity rate no longer increases when retiring at any age later than 65) would plausibly induce individuals to retire before being "penalized".

Finally, in case there is not a social security system individuals in the model turn out to optimally choose to retire late in their lifetime, after 69 years of work, corresponding to retirement at $t_{r e t}=70$ in the model, i.e. 90 (real-life) years.

\subsubsection{Introduction of Unbalanced Social Security}

A question to be tackled is whether and why the introduction of social security is ex-ante welfare improving for individuals in the model. The answer to this question serves in particular to investigate the magnitude of risk-insurance effects that are possibly brought about by social security.

Due to the features of the calibrated model (partial equilibrium setting, and no growth of the economy) all comparisons carried out in the paper consider one representative individual, belonging to one "representative" generation, under different settings.

The analysis firstly focuses on the case where the social security budget is possibly unbalanced in every period.

Simulations are run to compare the model's economic setting respectively in the absence and in the presence of a social security system. In the former scenario, individuals do not contribute to social security and do not receive pension benefits of any sort; in the latter scenario, the pension system is modeled so as to reproduce the pre-Amato regime, a quite standard PAYG DB system.

The analysis is performed in ex-ante terms at time zero before individuals enter the economy, through a comparison between the ex-ante expected discounted lifetime utility (i.e. between the value function at the beginning of life) under the two scenarios. The comparison is performed in terms of "Compensating Variation" (CV), i.e. in terms of 
the amount of assets that should be given to the individual in a setting (e.g. with social security) before the beginning of his life, in order to let him benefit from the same level of ex-ante expected discounted lifetime utility as he would enjoy in the other setting (e.g. without social security). If the introduction of social security under uncertainty turns out to decrease (increase) ex-ante utility level of individuals, then the Compensating Variation to be given to the individual in the setting with social security, in order to let him enjoy the same ex-ante utility level that he enjoyed without social security, is positive (negative).

After running simulations, the Compensating Variation $\left(C V_{S S}\right)$ to be given to the individual passing from a setting with no social security to a setting with a (pre-Amato) pension system turns out to be positive:

$$
C V_{S S}=461.4
$$

The positive sign means that the introduction of social security in the Italian simulated setting decreases individual welfare.

The above value of the Compensating Variation approximately corresponds to the sum of assets held by the representative individual in each of the first four years of working life in the absence of social security. Alternatively, the above value corresponds to roughly three times as much as the amount of the pension benefit received by a retiree in every period.

The welfare variation can also be measured by the so-called consumption equivalent, i.e. the percentage change in lifetime consumption that is needed to equalize ex-ante utility levels under different settings. In this case, individuals in the presence of social security should benefit from an increase by $14.9 \%$ in lifetime consumption in order to enjoy the same ex-ante welfare level they would enjoy in the absence of social security. ${ }^{10}$

\footnotetext{
${ }^{10}$ When comparing in the same way a setting without social security and a setting under a postDini system, it turns out that $C V_{S S}=657.4$. This value is roughly equal to the sum of assets held by the representative individual in each of the first five years of working life in the absence of social security, or alternatively to more than four times as much as the amount of the pension benefit received by a retiree in every period. The corresponding consumption equivalent measure equals an increase by $38.4 \%$ in lifetime consumption to be enjoyed by individuals under social security in
} 
This result is noteworthy in that it implies that the introduction of the statutory Italian social security scheme would decrease individual welfare despite the relative generosity of its (net) transfers.

The individual value functions (representing in every period the value of expected discounted utility from that period onwards) under the two settings, i.e. the absence of social security ("No SS") and the pre-Amato pension system ("Old regime"), are graphically reported in Figure 1. The lifetime value function in the setting without social security lies above the one in the setting with social security. This suggests that in the baseline scenario the introduction of a social security system decreases ex-ante welfare of individuals, measured as the value function at the beginning of life.

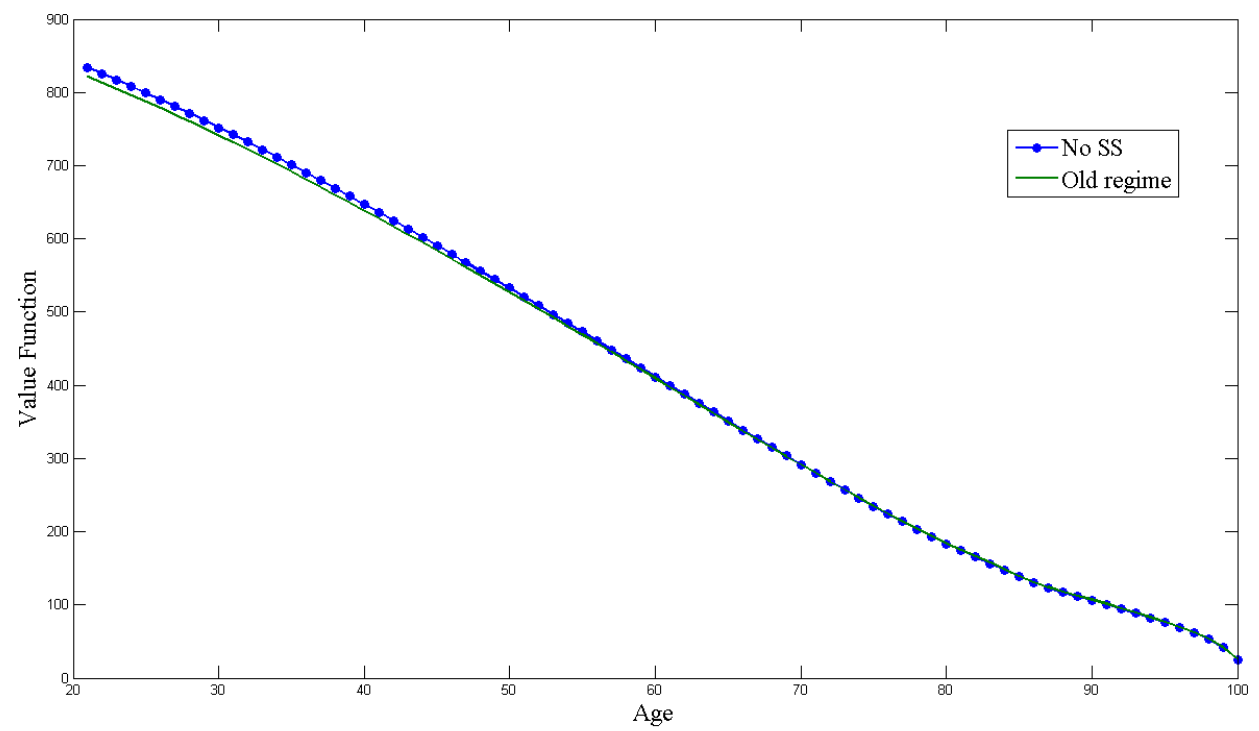

Figure 1: Value function, No social security vs Old regime

It is important to notice that when performing this comparison the underlying economic setting is kept the same: the actual underlying realizations of $w_{t}$ and $r_{t}$ from time order for them to obtain the same ex-ante welfare level as in the absence of social security. 
$t=1$ to time $t=T$ are the same, and all relevant parameters are kept constant, except for social security being absent or present. The only institutional variation between the two settings is represented by the introduction of a social security system, that makes individuals adjust their optimal lifetime paths for asset accumulation and leisure. ${ }^{11}$

As Fehr and Kotlikoff (1997) show in a general equilibrium setting, a part of the total policy-induced welfare variation is due to changes in individual behavior, i.e. in consumption (or asset accumulation) and leisure choices, as a response to the policy change. Therefore, in order to better evaluate the part of total ex-ante utility variation that is due to risk-insurance effects of social security, differences in individual behavior under different policy scenarios should be taken into account and somehow "eliminated" from the overall welfare effect.

A first attempt to partly account for this may consider a scenario where individuals are assumed to need to retire at $t=41$ (i.e. 61 real-world age) both in the absence and in the presence of social security (in the latter case it is also the optimal retirement age). ${ }^{12}$ In this case, the Compensating Variation to be given to the individual passing from a setting with no social security to a setting with a (pre-Amato) pension system is:

$$
C V_{S S}=-22948.5
$$

that is roughly equal in absolute value to ten times as much as the sum of assets held by the representative individual in each of the first 12 years of working life in the absence of social security. The negative sign of the Compensating Variation suggests that an increase in the ex-ante expected utility of individuals occurs after introducing a pension system $(\grave{a}$ la pre-Amato), in case individuals in the absence of social security are assumed to need

\footnotetext{
${ }^{11}$ In particular as regards retirement behavior, individuals in the absence of social security choose to retire at $t_{r e t}=70$, whereas in the presence of a social security system à la pre-Amato they choose to retire at $t_{r e t}=41$, and at $t_{r e t}=45$ under a system $\grave{a} l a$ post-Dini.

${ }^{12}$ Individuals in the absence of social security are assumed to need to retire at a previous age e.g. due to some exogenous reason, like worsening health conditions. This assumption may roughly compensate for the paper not explicitly taking into account health conditions of individuals through lifetime and particularly in the old age.
} 
to retire at a relatively early age $(t=41)$. Intuitively, in case individuals need to retire at a certain age they are better off in the presence of a pension system allowing them to substitute labor income with pension wealth in the old age (i.e. after they retire).

In order to totally take away all policy-induced changes in individual behavior, another comparison is performed simulating a setting where, on the one hand, the representative individual under the pre-Amato system is forced to choose the same lifetime assets and leisure paths as those he would choose in the no-social security scenario ${ }^{13}$; on the other hand, the individual in the absence of social security is again assumed to need to retire at the same age as the one he would choose under the pre-Amato pension system. While preventing the individual from optimizing over choice variables under both settings, these constraints make the ex-ante welfare change between the two settings only depend on differences in lifetime transfers (lifetime net taxes) and in risk-insurance effects.

Under these assumptions, the Compensating Variation $\left(C V_{\text {SSFixed }}\right)$ that should be given to the individual passing from a setting with no social security (where retirement is exogenously set at time $t=41$ ) to a setting with a pre-Amato pension system (where assets and leisure choices are kept fixed at the same level as in the absence of social security) turns out to be negative:

$$
C V_{\text {SSFixed }}=-66.4
$$

The above value of $C V_{\text {SSFixed }}$ is slightly higher in absolute value than the amount of assets held by the representative individual in the first year of working life in the absence of social security. Its negative sign implies a welfare gain from introducing social security. ${ }^{14}$

\footnotetext{
${ }^{13}$ The choice variables in the model's optimization problem are represented in every period $t$ by assets at the beginning of the subsequent period $\left(A_{t+1}\right)$ and leisure $\left(l_{t}\right)$.

${ }^{14} \mathrm{An}$ analogous comparison can be performed between a setting without social security (where retirement is exogenously set at time $t=45$ ) and a setting under a post-Dini system (where assets and leisure choices are kept fixed at the same level as in the absence of social security). In this case, the resulting Compensating Variation to individuals in the presence of social security turns out to be $C V_{\text {SSFixed }}=-60.3$, that qualitatively confirms the result under the pre-Amato system. This value of the Compensating Variation is slightly lower in absolute value than the amount of assets held by the representative individual in the first year of working life in the absence of social security.
} 
Obtaining a negative value of $C V_{\text {SSFixed }}$ however cannot be straightforwardly interpreted as suggesting that the introduction of social security brings about some riskinsurance effect. There is also another remaining component of ex-ante utility variation, that is due to the change in lifetime net taxes (transfers): this transfer component may be the main determinant of the above result, especially in case the Italian social security budget were to run within-period deficits. Secondly, because individuals in the absence of social security are penalized by being not allowed to optimize over retirement age.

Overall, risk-insurance effects of social security may be relatively small in magnitude (particularly as compared to the transfer component of ex-ante utility variation), and may not play a relevant role in driving ex-ante welfare gains and losses.

Regardless of the relative magnitude (possibly negligible) of the risk-insurance component out of the overall welfare variation, why may risk-insurance effects - even of small size - be brought about by social security in the analyzed statutory Italian setting? There seem to be two possible sources of welfare improvement related to risk insurance. On the one hand, the provision of annuities to retired individuals in the model prevents mortality risk from making them leave unintended bequests. On the other hand, a pension system à la pre-Amato (as well as à la post-Dini) where benefits are based on past wages, potentially provides retirees with a hedge against financial market risk in the old age. Such a pension system can provide ex-ante risk "diversification" between the wage-based pension and financial market returns earned on savings accumulated until retirement, since wages and market returns in the model are estimated to be imperfectly correlated.

\subsubsection{Introduction of Balanced Social Security}

In the above analyzed statutory setting, both the old and the new system turn out to cause within-period social security budget deficits. Under the statutory pre-Amato system the 
simulated within-period social security deficit ${ }^{15}$ is equal to:

$$
\text { SSdeficit } \text { pre-Amato }_{\text {Amo }}=1456.9
$$

whereas the within-period social security deficit under the statutory post-Dini system turns out to be:

$$
\text { SSdeficit }{ }_{\text {post-Dini }}=349
$$

The resulting deficit under the pre-Amato regime is approximately equal to the sum of assets held in each of the first nine working years by the representative individual in the economy, whereas the deficit under the post-Dini regime roughly equals the sum of assets held in each of the first five working years by the representative individual in the economy. ${ }^{16}$

The analysis therefore moves on to investigating the case where the social security budget is forced to balance in every period, i.e. not to run a deficit nor a surplus.

Under this assumption, the understanding of whether the introduction of social security into the Italian economy is potentially ex-ante welfare improving relates to conditions for "optimality" of social security, i.e. institutional conditions under which both social security budget balance and maximization of individuals' utility occur.

Policy parameters (i.e. replacement rate under the pre-Amato system and the annuity rate under the post-Dini system) are assumed to vary so as to get social security budget exactly balanced under both systems, for every given level of the contribution rate. ${ }^{17}$ The optimal size of the social security system is therefore represented by the value of the contribution rate (denoted as $h^{*}$ ) which maximizes individuals' welfare (in ex-ante terms)

\footnotetext{
${ }^{15}$ In the model the simulated within-period deficit (resulting on average across 10000 simulations) is roughly constant at every time, therefore a single "representative" period is taken as reference.

${ }^{16}$ The budget gain under the new regime is in line with the literature on Italian pension reforms. The simulated value of this gain (roughly 1100 in terms of reduced within-period deficit) is approximately equal to the sum of assets held by the representative individual in each of the first eight working years under the old regime, or alternatively to ten times as much as the amount of the pension benefit received by the representative individual in every period of retirement under the old system.

${ }^{17}$ That is to say, both replacement rate (under the old regime) and annuity rate (under the new regime) are treated as functions of the contribution rate.
} 
while satisfying social security budget balance condition.

From simulations it turns out that the optimal size of the contribution rate (thus, of social security) is positive although close to zero: $h_{\text {pre-Amato }}^{*}=h_{\text {post-Dini }}^{*}=0.001$, i.e. $0.1 \%$ under both the pre-Amato and the post-Dini system.

This means optimality requiring that there is a small social security system. The corresponding optimal retirement age under both systems turns out to be $t_{\text {ret }}=69$, i.e. 89 years in real life.

This result is robust to different specifications of the model. It still holds in case survival probabilities are higher than in the baseline setting (including the case in which there is no uncertainty on death, i.e. $\psi(t)=1$ in every period $t$ ), as well as in case preference parameters are allowed to vary within a broad range of reasonable values.

A second analysis is performed by keeping retirement age exogenously fixed at a given threshold. This assumption is meant to reflect e.g. worsening health conditions of individuals (some health shock) forcing them to retire at a given age. When exogenously setting the retirement age at $t=41$ (61 real-world age), the optimal size of the social security system turns out to be $h_{\text {pre-Amato }}^{*}=h_{\text {post-Dini }}^{*}=0.035$, i.e. $3.5 \%$ under both the pre-Amato and the post-Dini system.

When instead exogenously setting the retirement age at $t=45,65$ real-world age ${ }^{18}$, the optimal contribution rate turns out to be $h_{\text {pre-Amato }}^{*}=h_{\text {post-Dini }}^{*}=0.02$, i.e. $2 \%$ under both the pre-Amato and the post-Dini system.

The reason why both systems yield the same optimal contribution rate (and retirement age, if endogenously determined) is that under optimality and budget-balance conditions the pre-Amato and the post-Dini regime induce individuals to choose (almost) equal asset

\footnotetext{
${ }^{18}$ The 65 retirement age corresponds to the eligibility requirement to receive the so-called "old age pension" ("pensione di vecchiaia"), set by the Amato reform at 65 for males (60 for females). The "old age pension" is provided to those individuals who turn 65 (for males, 60 for females), conditional on paying contribution for at least 20 years. Therefore 65 can be meant to represent a sort of age threshold after which individuals in the "real world" find it hard to continue working due to their health conditions.
} 
and leisure paths over their lifetime, and yield equal pension benefit levels.

The optimal dimension of social security is in all cases much lower than the actual dimension of the real Italian statutory setting, where contribution rates are approximately $24 \%$ under the old regime and $33 \%$ under the new regime. ${ }^{19}$

Under budget balance restrictions positive transfer effects of statutory pension systems are substantially reduced. Therefore the very low optimal size of the balanced pension scheme seems to confirm the guessing of the previous subsection, namely that risk insurance effects of social security are plausibly relatively small and do not considerably drive welfare gains and losses.

\subsubsection{Comparison between Different Regimes}

After analyzing the introduction of social security in the Italian economic setting, a comparison is carried out between the two regimes considered in the paper, i.e. the pre-Amato and the post-Dini regimes, that are at first modeled according to their statutory features. While being applied to the Italian institutional setting, this comparison is basically between a typical DB system and a notional DC system.

The comparison is performed by analyzing the effects of different pension systems on the welfare of a given representative individual entering the economy at time $t=1$.

The first general result is that the pre-Amato regime is more beneficial in welfare terms than the post-Dini regime. The Compensating Variation $\left(C V_{N e w}\right)$ from the old to the new regime (namely, the amount of assets compensating individuals under the new regime to let them enjoy an ex-ante expected lifetime utility level equal to that enjoyed by individuals under the old regime) is indeed positive:

\footnotetext{
${ }^{19}$ It is worth stressing that the optimal size of social security turns out to increase as the expected average return on financial assets $\left(r_{t}\right)$ is exogenously assumed to decrease with respect to the baseline case (where the average financial return is roughly $6.6 \%$ ). However even when considerably decreasing financial returns the optimal contribution rate increases only slightly and remains much lower than the actual size of the real Italian statutory setting.
} 


$$
C V_{\text {New }}=364.8
$$

The above value approximately amounts to the sum of assets held by the representative individual in each of the first four years of working life under the old pension system. ${ }^{20}$

Value functions through time confirm, under this first comparison, the overall superiority of the old regime in terms of expected lifetime utility, as it is shown in Figure 2. The lifetime value function in the setting with the old pension system lies slightly above the one in the setting with the new pension system.

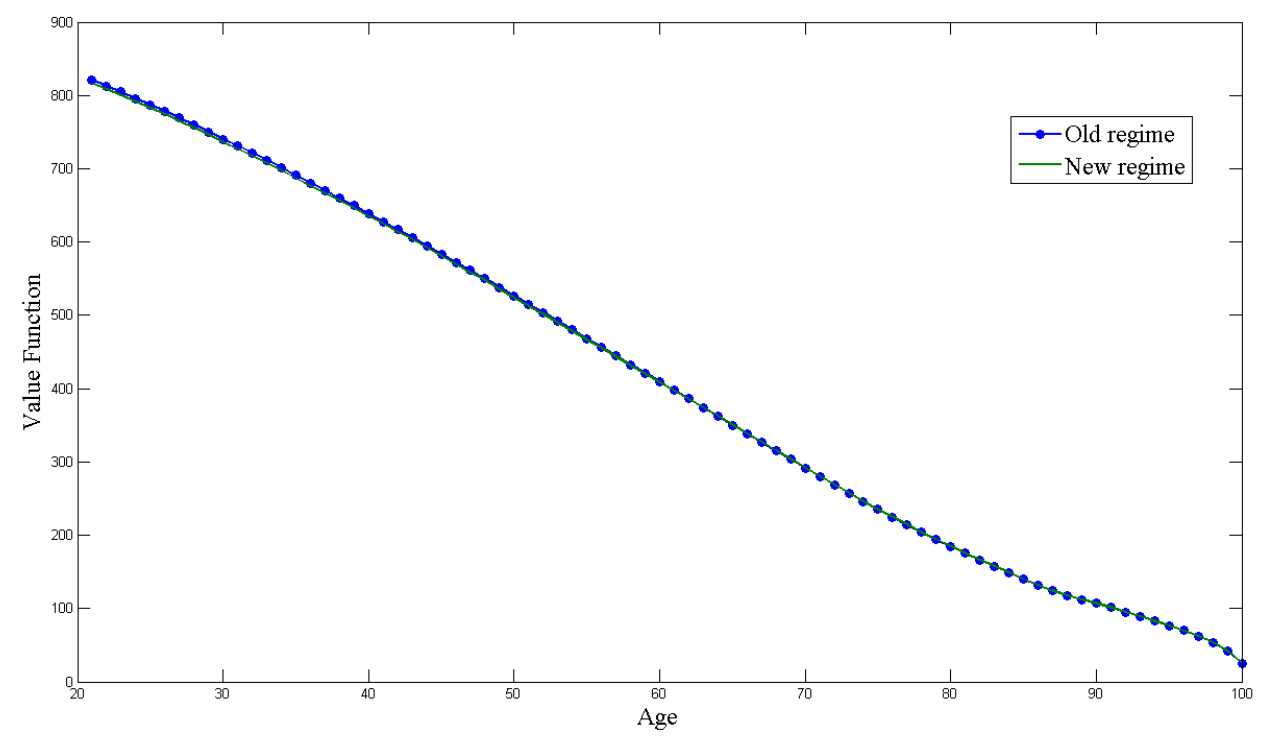

Figure 2: Value function, Old regime vs New regime

However, the two regimes are subject to different statutory rules, implying different lifetime transfers, namely different contributions and pension benefit levels. Moreover, the welfare comparison between the two systems is also misled by the fact that individuals

\footnotetext{
${ }^{20}$ Alternatively, the value of the Compensating Variation amounts to two and a half times the amount of the pension benefit received by the retired individual under the pre-Amato system. The corresponding consumption equivalent measure equals an increase by $9.8 \%$ in lifetime consumption to be enjoyed by individuals under the new regime in order for them to obtain the same ex-ante welfare level as under the old regime.
} 
under the old regime in the model retire at an earlier age (after 40 years of work) than individuals under the new regime (retiring after 44 years of work). A more accurate comparison aiming at investigating the merely risk-insurance impacts of social security requires those differences across systems to be taken away.

Differences in lifetime transfers can be eliminated through exogenously equalizing the contribution rate and the ex-ante possible levels of pension benefits across the two regimes. The contribution rate under both systems is set at the pre-Amato level $(h=0.24)$. Moreover the post-Dini annuity rate is set at such a level that ensures its pension benefits are ex-ante equal in expected value to those provided under the pre-Amato scheme. ${ }^{21}$

When performing a comparison under such assumptions, it turns out that the Compensating Variation is negative:

$$
C V_{\text {New }}=-0.0304
$$

The amount of the Compensating Variation is equal in absolute value to a small fraction $(0.08 \%)$ of the amount of assets accumulated in the first period of life by the representative individual. The negative sign means that the ex-ante expected lifetime utility under the new regime is slightly greater than under the old regime. This result is crucial in the analysis carried out in the paper, in that it suggests that the post-Dini system, when all statutory differences across systems are eliminated, is potentially ex-ante welfare improving, and this improvement is due to its better risk diversification properties with respect to the pre-Amato system.

This result is qualitatively robust to variations in the preference parameters of the model, as well as to variations in those parameters that are mostly related to uncertainty such as the correlation between wages and market returns, and the variances of wages and market returns.

\footnotetext{
${ }^{21}$ The statutory annuity rate ("transformation coefficient") for individuals retiring at 61 is equal to 0.05334 . In order to equalize the ex-ante possible values of pension benefits, this coefficient is increased in the simulation to 0.0873 .
} 
In particular, as the variance (i.e. the riskiness) of wages increases, the post-Dini system turns out to become more beneficial with respect to the pre-Amato system (the Compensating Variation becomes slightly lower, thus higher in absolute value), thereby confirming its better ex-ante risk-insurance properties stemming from diversification of wage risks across all working life wages. The reference Compensating Variation under the above assumptions is $C V_{\text {New }}=-0.0304$. In case the variance of the stochastic component of wages is assumed to be twice as much as that in the baseline case, i.e. $\sigma_{w}^{2}=5.9864$, with all other parameters remaining unchanged, the resulting Compensating Variation turns out to slightly decrease (increase in absolute value) and to equal $C V_{\text {New }}=-0.0609$. When a still higher variance is assumed, being four times as much as that in the baseline case, i.e. $\sigma_{w}^{2}=11.9728$, the Compensating Variation further decreases and amounts to $C V_{\text {New }}=-0.1216$.

The reason why the Compensating Variation $(-0.0304)$ resulting from the last comparison is solely due to the risk-insurance component of the overall utility variation is that the other components are neutralized. Not only has the transfer component been eliminated (through equalizing the contribution rate and the possible pension levels across the two systems), but also the component due to changes in individual behavior has been neutralized. Individuals under the two systems are equal, face the same realizations of wages and rates of return in every period ${ }^{22}$, and receive (or pay) the same lifetime transfers in expected value: their simulated labor/leisure (notably, retirement) choices as well as consumption/saving choices turn out to be the same (or different to a negligible extent) across the two systems. ${ }^{23}$

The only non-zero utility-variation component is the one related to risk insurance,

\footnotetext{
${ }^{22}$ The comparison is focused on the welfare of a given representative individual under different pension systems. The underlying macroeconomic setting remains therefore the same across systems.

${ }^{23}$ The result in terms of Compensating Variation is indeed the same in case simulations are run while exogenously keeping optimal choices (leisure and assets) under the old system fixed under the new system.
} 
resulting from a difference in the ex-ante probabilities of different pension levels occurring. This difference is due to the benefit computation rules under the two systems: while the pre-Amato system provides benefits based on only the last five years of working life, the post-Dini system provides pension benefits based on all working life contributions (and thus wages). Therefore the new regime ex-ante reduces the variance of pension benefits by causing higher probability of mean benefit values occurring and lower probability of tail values (low and high benefits) occurring. ${ }^{24}$ Even in case the ex-ante possible levels of pension benefits, and thus their expected (mean) value, are made equal under the two systems, risk-averse individuals enjoy a small ex-ante welfare gain resulting from reduced variability of pension benefits, given equalized level of the contribution rate and equal endogenous choices on assets and leisure.

Consequently the Dini reform is potentially beneficial to individuals from a purely risk-insurance perspective. From such perspective, what mostly differs across systems is the degree of ex-ante risk diversification over uncertain working-life wages, depending on the number of yearly wages (contributions) entering the benefit formula. The longer the working period (wages or contributions) entering the pension benefit formula, the lower the variance of pension benefits, namely the higher the wage risk diversification ${ }^{25}$, and thus the greater the ex-ante expected utility to risk-averse individuals.

Nevertheless, the welfare gain to individuals under the new system is quite small (i.e. $\mathrm{CV}$ is very small in absolute value as compared to assets accumulated by individuals in the model), meaning that risk-insurance properties differ only slightly under the pre-

\footnotetext{
${ }^{24}$ When equally grouping pension benefits into three levels, under the simulated pre-Amato system the ex-ante probability of a "low" pension benefit occurring is 0.18715 , of a "mean" pension benefit 0.6257 , and of a "high" pension benefit 0.18715 , for every age at which the individual chooses to retire. Under the post-Dini system with the individual retiring at $t_{r e t}=45$ (respectively, 41), instead, the ex-ante probability of a "low" pension benefit level occurring is 0.0199 (0.02415), of a "mean" benefit level 0.9602 (0.9517), and of a "high" pension benefit level 0.0199 (0.02415).

${ }^{25}$ This effect crucially depends on wages being only partially auto-correlated through time, as it seems to be the case in reality. If wages were exogenously assumed to be serially uncorrelated, i.e. with auto-correlation falling to zero, the advantage from the post-Dini system would slightly increase as the resulting Compensating Variation would become $C V_{N e w}=-0.0307$.
} 
Amato and the post-Dini regime. In particular, risk-insurance differences across the two systems are outweighed in magnitude by differences in lifetime (net) transfers: $C V_{N e w}$ in the baseline scenario (364.8) is considerably larger than the absolute value of $C V_{N e w}$ in the "risk-insurance" analysis $(-0.0304)$.

In order to further delve into the previous points, a final comparison can be made between the post-Amato/pre-Dini system and the post-Dini system. If such a comparison is performed, after eliminating all differences causing different transfers under the two systems ${ }^{26}$, it turns out that the Compensating Variation $\left(C V_{\text {NewAmato }}\right)$ to individuals passing from the post-Amato to the post-Dini system is equal to zero:

$$
C V_{\text {AmatoNew }}=0
$$

This means that, after accounting for all differences in transfers, the post-Amato and the post-Dini system do not differ as regards ex-ante risk-insurance properties, and both regimes turn out to be slightly ex-ante welfare improving with respect to the old (preAmato) regime. The reason is clearly that both the Amato and the Dini reform cause an improved diversification of wage risks, by tying pension benefits to all wages (or contributions) earned during working life, whereas the pre-Amato system provides pension benefits based on a shorter series of wages.

\section{Concluding Remarks}

The paper has analyzed social security effects in a setting marked by uncertainty at the individual level and at the aggregate macroeconomic level, with reference to the Italian

\footnotetext{
${ }^{26}$ Contribution rate and pension benefit levels are exogenously kept equal under the post-Amato system and the post-Dini system. The contribution rate under the post-Amato setting is thus set at $h=0.33$, and the replacement rate is set at 1.33 (instead of the statutory 0.8 ) in order to ex-ante equalize pension benefits levels. As in the previous comparison, the elimination of differences in lifetime transfers induces individuals to make the same (or negligibly different) consumption/saving and leisure choices, so that no (or negligible) changes in individuals' behavior occur when shifting from the post-Amato to the post-Dini system.
} 
economy. The analysis is carried out in a "steady state" scenario, and focuses on a representative individual belonging to a given generation.

The investigation has been carried out starting with a preliminary analysis of impacts brought about by the introduction of a PAYG social security system in the Italian economy.

In the statutory setting, allowing social security budget to run within-period deficits, the introduction of social security in the simulated Italian economy turns out to decrease ex-ante individual welfare, despite relatively generous pension transfers. Only in case individuals are exogenously assumed to retire at a relatively early age (e.g. due to some "shock" worsening their health conditions), the introduction of social security turns out to improve their welfare level.

In a setting where the social security budget is forced to balance in every period, the optimal size of both the old and the new Italian pension system (expressed in terms of the contribution rate) turns out to be positive, although quite small and considerably lower than the actual statutory size.

The research has then investigated the impacts of different pension regimes introduced in Italy, particularly by comparing the old DB system with the new NDC system. The main result is that, after accounting for differences in lifetime transfers, the new pension system potentially brings about a slight ex-ante welfare improvement. This positive effect is due to the better risk-insurance properties of the new regime, stemming from enhanced risk diversification throughout working-life wages in determining pension benefits.

Overall, risk-insurance effects brought about by the introduction of social security plausibly play a minor role in determining total welfare variations, and are clearly outweighed in magnitude by other components, notably by changes in lifetime transfers. 


\section{Appendix}

\subsection{Data and Methodology}

Stochastic processes for real market returns and wages have been estimated by considering available historical series for Italy over the period 1990-2004. The reason why a relatively short time span is considered is that for period 1990-2004 almost all needed data are available. In order to obtain better estimates from an econometric point of view, data have been taken at a quarterly frequency, so as to work on 60 observations instead of 15 .

As for data sources, data on wages have been found in the OECD (2008) data set, with "Compensation per employee in total economy" being the OECD entry that has been utilized, since it is a measure of gross wages in the overall economy (comprising both public and private sector).

Average market returns are computed as the weighted average of historical returns on three major financial assets held by Italian households: government bonds, corporate bonds issued by Italian banks, and stocks issued by Italian companies.

Returns on government bonds have been computed as the non-weighted average yield on two main types of Italian government bonds, namely short-term bonds (BOT - Italian T-bills) and medium-to-long-term bonds (BTP - Italian T-bonds). As for returns on BOTs the source is the "Ministero dell'Economia" web site, providing BOT returns at issue. As regards BTPs return, the Bank of Italy "Rendistato" yield is utilized, since it reflects the average market performance of BTPs traded on the Electronic Bond and Government Securities Market (MOT) of the Italian Stock Exchange.

Returns on corporate bonds issued by banks constitute the great majority of all Italian corporate bonds. Their return is reported by the Bank of Italy "Rendiob" yield, reflecting the average market performance of corporate bonds issued by banks and traded on the Electronic Bond and Government Securities Market (MOT) of the Italian Stock Exchange. 
The "Rendiob" index is available only from the end of the 1980s to 2004.

As for stocks, shares of listed companies have been deemed as representative of shares of all Italian companies. Average returns on stocks have been computed using the COMIT Performance - Total Return index, which includes total returns (both prices and dividends) of all shares listed on the Stock Electronic Market (MTA) of the Italian Stock Exchange.

All of the three above mentioned types of returns have then been weighted considering the yearly portfolio composition of Italian households reported by the Bank of Italy (2007), referring to the period 1995 through 2006. Weights are computed as percentages of "Italian government bonds", "Italian corporate bonds issued by banks" and "shares issued by residents" in a simplified portfolio held by Italian households, namely a portfolio made up of only those three categories of securities. In the absence of data on portfolio composition relative to the 1990-1994 period, weights for returns in those years have been assumed to be the same as those in year 1995. Moreover, when considering observations at a quarterly frequency, the yearly weights are assumed to be the same throughout all quarters of every year.

The average yearly "seniority" wage growth rate $s w$ has been computed as the difference between two terms: the approximate yearly average growth rate of real wages earned by a specific cohort from 1976 to 2004 (Italian workers entering the labor market in 1976 when 21/22 years old); minus the average yearly aggregate growth rate of wages in Italy throughout the period 1976-2004. Computing this difference is aimed at obtaining a cohort-specific measure of "seniority" wage growth. This measure is then assumed to stay constant through time, and through generations, in the model. Data on aggregate wages have been collected from OECD (2008) data base; data on the wage dynamics of the cohort that entered the labor market in 1976 have been deduced by a rough analysis of data reported by Rosolia and Torrini (2007).

Data utilized to compute the aggregate growth rate $(g)$ of real wages in Italy in different 
historical periods have been found in OECD (2008) data source.

Data on social security contribution rates $(h)$ have been found at INPS (National Institute of social security) web site. Estimates on the actual replacement rate under the pre-Amato system are reported in OECD (2007).

All demographic data and projections are provided by the yearly demographic balance of Istat (National Institute of Statistics) web site.

\subsection{Optimization Problem and Simulation Procedure}

The model solution is based on optimization following finite-horizon stochastic dynamic programming. Since an analytical solution to the optimization problem can not be obtained, simulations have been run in order to solve the problem numerically. These simulations have been performed by utilizing a numerical simulation software program.

In order to take into account the fact that wages $(w)$ and market returns $(r)$ are stochastic variables, a randomization has been performed by letting the software program randomly draw 10000 values for $w_{t}$ and $r_{t}$ from their respective stationary distributions in every period $t$. The reason why in every model period 10000 simulations are run is to obtain simulated results that are not dependent on one single randomization. Consequently, 10000 optimal assets (thus consumption) and leisure paths have been obtained, as well as 10000 pension benefit levels. The values of these variables reported in the paper have been obtained by averaging out across the 10000 trials in every period.

Wages and market returns in the model have been discretized into three states ("low", "mean" and "high") each, in order to numerically solve the optimization problem. Stochastic processes for wages and financial market returns (autoregressive and serially uncorrelated, respectively) have been approximated by Markov chains through the Tauchen procedure (Tauchen 1986, pp. 177-181) so as to be discretized. This procedure yields stationary transition matrices for both wages and market returns, representing the con- 
ditional probabilities of passing from one state in a given period $t$ to another state in the subsequent period $t+1$.

Like wages, pension benefits have been accordingly discretized into three possible states ("low", "mean" and "high") in order to run simulations.

As above anticipated, in numerically solving the optimization problem the choice variables for the individual in every period $t$ are represented by leisure $\left(l_{t}\right)$ and asset holdings at the beginning of the next period $\left(A_{t+1}\right)$.

The assets variable has been discretized into a grid of points representing different values for asset holdings of individuals. The number of equally spaced grid points is 25 , with the minimum grid value for assets being 0 (individuals cannot borrow in the model economy), and the maximum grid value being 300 .

In most simulations within-period time endowment $(\bar{T})$ has been normalized to 2 . This normalization of the per-period time endowment to two units turns out to be useful in calibrating the model for computational reasons. Within-period leisure in the model, $l_{t}$, has been discretized so as to take on nine possible grid values from zero to (mostly) two. In the baseline calibrated model individuals choose to work approximately 1 unit of time (enjoying 1 time unit of leisure) during working life, whereas they enjoy the whole time endowment after retirement. 


\section{References}

Auerbach, A.J., J. Gokhale and L.J. Kotlikoff (1991), "Generational Accounts: A Meaningful Alternative to Deficit Accounting", in D. Bradford, eds., Tax Policy and the Economy, MIT Press, Cambridge, MA, pp. 55-110.

Ball, L. and N.G. Mankiw (2007), "Intergenerational Risk Sharing in the Spirit of Arrow, Debreu, and Rawls, with Applications to Social Security Design", Journal of Political Economy 115, 523-547.

Bank of Italy (2007), Household Wealth in Italy 1995-2005 - Supplements to the Statistical Bulletin, http://www.bancaditalia.it/statistiche/

Barr, N. and P.A. Diamond (2006), "The Economics of Pensions", Oxford Review of Economic Policy 22(1), 15-39.

Battistin, E., A. Brugiavini, E. Rettore and G. Weber (2008), "The Retirement Consumption Puzzle: Evidence from a Regression Discontinuity Approach", Working paper, Institute for Fiscal Studies, London.

Campbell, J.Y. and Y. Nosbusch (2007), "Intergenerational Risksharing and Equilibrium Asset Prices", Journal of Monetary Economics 54, 2251-2268.

Cardarelli, R. and N. Sartor (2000), "Generational Accounting for Italy", in Bank of Italy, eds., Fiscal Sustainability, Rome, pp. 501-557.

Enders, W. and H.E. Lapan (1982), "Social Security Taxation and Intergenerational Risk Sharing", International Economic Review 23, 647-658.

Fehr, H. and L.J. Kotlikoff (1997), "Generational Accounting in General Equilibrium", Working paper, NBER, Cambridge, MA.

Fonseca, R. and T. Sopraseuth (2005), "Welfare Effects of Social Security Reforms Across Europe: the Case of France and Italy", Working paper, Centre for Studies in Economics and Finance, Salerno, Italy.

Friedman, B.M. and M.J. Warshawsky (1990), "The Cost of Annuities: Implications 
for Saving Behavior and Bequests", The Quarterly Journal of Economics 105(1), 135-154.

Gottardi, P. and F.E. Kubler (2009), "Social Security and Risk Sharing", Working paper, European University Institute, Florence, Italy.

Guazzarotti, G. and P. Tommasino (2008), "The Annuity Market in an Evolving Pension System: Lessons from Italy", Working paper, Center for Research on Pensions and Welfare Policies, Turin, Italy.

Krueger, D. and F.E. Kubler (2006), "Pareto Improving Social Security Reform when Financial Markets are Incomplete!?", American Economic Review 96(3), 737-755.

Imrohoroglu, A., S. Imrohoroglu and D.H. Joines (1995), "A Life Cycle Analysis of Social Security", Economic Theory 6(1), 83-114.

Merton, R.C. (1983), "On the role of Social Security as a means for efficient risk sharing in an economy where human capital is not tradeable", in Z. Bodie and J.B. Shoven, eds., Financial Aspects of the United States Pension System, The University of Chicago Press, Chicago, pp. 325-358.

Miniaci, R., C. Monfardini and G. Weber (2003), "Is there a retirement consumption puzzle in Italy?", Working paper, Institute for Fiscal Studies, London.

OECD (2007), Pensions at a Glance: Public Policies across OECD Countries - 2007 Edition, http://lysander.sourceoecd.org/vl=11817715/cl=18/nw=1/rpsv/6682/v2007n7/s1/p1l

OECD (2008), OECD Economic Outlook: Annual and quarterly data Vol 2008 Issue 1, http://puck.sourceoecd.org/vl=21343945/cl=19/nw=1/rpsv/ 3770/v2008n1/s1/p1l

Rosolia A. and R. Torrini (2007), "The Generation Gap: Relative Earnings of Young and Old Workers in Italy", Working paper, Bank of Italy, Rome.

Sartor, N. (2001), "The Long-Run Effects of the Italian Pension Reforms", International Tax and Public Finance 8(1), 83-111.

Tauchen, G. (1986), "Finite State Markov-Chain Approximations to Univariate and Vector Autoregressions", Economic Letters 20, 177-181. 


\section{CESifo Working Paper Series}

for full list see www.cesifo-group.org/wp

(address: Poschingerstr. 5, 81679 Munich, Germany, office@cesifo.de)

2749 Rüdiger Pethig and Christian Wittlich, Interaction of Carbon Reduction and Green Energy Promotion in a Small Fossil-Fuel Importing Economy, August 2009

2750 Kai Carstensen, Oliver Hülsewig and Timo Wollmershäuser, Monetary Policy Transmission and House Prices: European Cross-country Evidence, August 2009

2751 Olaf Posch, Explaining Output Volatility: The Case of Taxation, August 2009

2752 Beatrice Scheubel, Daniel Schunk and Joachim Winter, Don't Raise the Retirement Age! An Experiment on Opposition to Pension Reforms and East-West Differences in Germany, August 2009

2753 Daniel G. Arce, Dan Kovenock and Brian Roberson, Suicide Terrorism and the Weakest Link, August 2009

2754 Mario Larch and Wolfgang Lechthaler, Comparative Advantage and Skill-Specific Unemployment, August 2009

2755 Horst Raff and Nicolas Schmitt, Buyer Power in International Markets, August 2009

2756 Seppo Kari, Hanna Karikallio and Jukka Pirttilä, The Impact of Dividend Taxation on Dividends and Investment: New Evidence Based on a Natural Experiment, August 2009

2757 Mirco Tonin and Michael Vlassopoulos, Disentangling the Sources of Pro-social Behavior in the Workplace: A Field Experiment, August 2009

2758 Nicole Grunewald and Inmaculada Martínez-Zarzoso, Driving Factors of Carbon Dioxide Emissions and the Impact from Kyoto Protocol, August 2009

2759 Yu-Fu Chen and Michael Funke, Booms, Recessions and Financial Turmoil: A Fresh Look at Investment Decisions under Cyclical Uncertainty, August 2009

2760 Jan-Egbert Sturm and Jakob de Haan, Does Central Bank Communication really Lead to better Forecasts of Policy Decisions? New Evidence Based on a Taylor Rule Model for the ECB, August 2009

2761 Larry Karp, Sacrifice, Discounting and Climate Policy: Five Questions, August 2009

2762 Marianna Belloc and Samuel Bowles, International Trade, Factor Mobility and the Persistence of Cultural-Institutional Diversity, August 2009

2763 Charles Noussair and Fangfang Tan, Voting on Punishment Systems within a Heterogeneous Group, August 2009 
2764 Birgit Bednar-Friedl and Karl Farmer, Internationally Coordinated Emission Permit Policies: An Option for Withdrawers from the Kyoto Protocol?, August 2009

2765 Pierre M. Picard and David E. Wildasin, Labor Market Pooling, Outsourcing and Labor Contracts, August 2009

2766 Stefan Voigt and Lorenz Blume, The Economic Effects of Federalism and Decentralization - A Cross-Country Assessment, August 2009

2767 David S. Jacks, Christopher M. Meissner and Dennis Novy, Trade Booms, Trade Busts, and Trade Costs, August 2009

2768 Mario Jametti and Thomas von Ungern-Sternberg, Hurricane Insurance in Florida, August 2009

2769 Alessandro Balestrino, Kind of Black: The Musicians' Labour Market in Italy, August 2009

2770 Yosr Abid Fourati and Cathal O’Donoghue, Eliciting Individual Preferences for Pension Reform, August 2009

2771 Christian Breuer and Chang Woon Nam, VAT on Intra-Community Trade and Bilateral Micro Revenue Clearing in the EU, August 2009

2772 Choudhry Tanveer Shehzad, Jakob De Haan and Bert Scholtens, Growth and Earnings Persistence in Banking Firms: A Dynamic Panel Investigation, August 2009

2773 Erdal Yalcin, Uncertain Productivity Growth and the Choice between FDI and Export, August 2009

2774 Klaus Abberger, Wolfgang Nierhaus and Shynar Shaikh, Findings of the Signal Approach for Financial Monitoring in Kazakhstan, September 2009

2775 Sascha O. Becker, Francesco Cinnirella and Ludger Woessmann, The Trade-off between Fertility and Education: Evidence from before the Demographic Transition, September 2009

2776 Thomas Aronsson and Erkki Koskela, Optimal Income Taxation, Outsourcing and Policy Cooperation in a Dynamic Economy, September 2009

2777 Joel Slemrod, Old George Orwell Got it Backward: Some Thoughts on Behavioral Tax Economics, September 2009

2778 Cagri Seda Kumru and Athanasios C. Thanopoulos, Social Security Reform and Temptation, September 2009

2779 Alessandro Bucciol and Roel M. W. J. Beetsma, Inter- and Intra-generational Consequences of Pension Buffer Policy under Demographic, Financial and Economic Shocks, September 2009 
2780 Eduardo Strube and Marcelo Resende, Complementarity of Innovation Policies in the Brazilian Industry: An Econometric Study, September 2009

2781 Henry Tulkens and Vincent van Steenberghe, "Mitigation, Adaptation, Suffering": In Search of the Right Mix in the Face of Climate Change, September 2009

2782 Maria L. Loureiro, Anna Sanz-de-Galdeano and Daniela Vuri, Smoking Habits: Like Father, Like Son, Like Mother, Like Daughter, September 2009

2783 Momi Dahan, Tehila Kogut and Moshe Shalem, Do Economic Policymakers Practice what they Preach? The Case of Pension Decisions, September 2009

2784 Eytan Sheshinski, Uncertain Longevity and Investment in Education, September 2009

2785 Nannette Lindenberg and Frank Westermann, How Strong is the Case for Dollarization in Costa Rica? A Note on the Business Cycle Comovements with the United States, September 2009

2786 Leif Danziger, Noncompliance and the Effects of the Minimum Wage on Hours and Welfare in Competitive Labor Markets, September 2009

2787 Gerlinde Fellner, Rupert Sausgruber and Christian Traxler, Testing Enforcement Strategies in the Field: Legal Threat, Moral Appeal and Social Information, September 2009

2788 Gabriel J. Felbermayr, Mario Larch and Wolfgang Lechthaler, Unemployment in an Interdependent World, September 2009

2789 Sebastian G. Kessing, Federalism and Accountability with Distorted Election Choices, September 2009

2790 Daniel Gros, Global Welfare Implications of Carbon Border Taxes, September 2009

2791 Louis N. Christofides, Michael Hoy and Ling Yang, The Gender Imbalance in Participation in Canadian Universities (1977-2005), September 2009

2792 Jan K. Brueckner and Robert W. Helsley, Sprawl and Blight, September 2009

2793 Vidar Christiansen and Stephen Smith, Externality-correcting Taxes and Regulation, September 2009

2794 John Beirne, Guglielmo Maria Caporale, Marianne Schulze-Ghattas and Nicola Spagnolo, Global and Regional Spillovers in Emerging Stock Markets: A Multivariate GARCH-in-mean Analysis, September 2009

2795 Rüdiger Pethig and Frieder Kolleß, Asymmetric Capital-Tax Competition, Unemployment and Losses from Capital Market Integration, September 2009

2796 Ngo Van Long, Horst Raff and Frank Stähler, Innovation and Trade with Heterogeneous Firms, September 2009 
2797 Margit Osterloh and Bruno S. Frey, Research Governance in Academia: Are there Alternatives to Academic Rankings?, September 2009

2798 Thiess Buettner and Clemens Fuest, The Role of the Corporate Income Tax as an Automatic Stabilizer, September 2009

2799 Annette Alstadsæter, Measuring the Consumption Value of Higher Education, September 2009

2800 Peter Friedrich, Chang Woon Nam and Janno Reiljan, Local Fiscal Equalization in Estonia: Is a Reform Necessary?, September 2009

2801 Evžen Kočenda and Jan Hanousek, State Ownership and Control in the Czech Republic, September 2009

2802 Michael Stimmelmayr, Wage Inequality in Germany: Disentangling Demand and Supply Effects, September 2009

2803 Biswa N. Bhattacharyay, Towards a Macroprudential Surveillance and Remedial Policy Formulation System for Monitoring Financial Crisis, September 2009

2804 Margarita Katsimi, Sarantis Kalyvitis and Thomas Moutos, "Unwarranted" Wage Changes and the Return on Capital, September 2009

2805 Christian Lessmann and Gunther Markwardt, Aid, Growth and Devolution, September 2009

2806 Bas Jacobs and Dirk Schindler, On the Desirability of Taxing Capital Income to Reduce Moral Hazard in Social Insurance, September 2009

2807 Hans Gersbach and Noemi Hummel, Climate Policy and Development, September 2009

2808 David E. Wildasin, Fiscal Competition for Imperfectly-Mobile Labor and Capital: A Comparative Dynamic Analysis, September 2009

2809 Johan Eyckmans and Cathrine Hagem, The European Union's Potential for Strategic Emissions Trading through Minimal Permit Sale Contracts, September 2009

2810 Ruediger Bachmann and Christian Bayer, The Cross-section of Firms over the Business Cycle: New Facts and a DSGE Exploration, October 2009

2811 Slobodan Djajić and Michael S. Michael, Temporary Migration Policies and Welfare of the Host and Source Countries: A Game-Theoretic Approach, October 2009

2812 Devis Geron, Social Security Incidence under Uncertainty Assessing Italian Reforms, October 2009 